\title{
Factors Refraining Medical Students from Blood Donation; a Tertiary Care Experience from a Medical College of Pakistan
}

\author{
Muhammad Tayyab Shera ${ }^{1}$, Asim Haider ${ }^{1}$, Syeda Beenish Bareeqa ${ }^{2}$, Syed Ijlal Ahmed ${ }^{3}$, \\ Muhammad Mashkat Junaid ${ }^{1}$, Zubair Khalid1, Frasat Ullah ${ }^{1}$ \\ ${ }^{1}$ Mayo Hospital, King Edward Medical University, Lahore, Pakistan \\ ${ }^{2}$ Jinnah Medical and Dental College, Karachi, Pakistan \\ ${ }^{3}$ Darus Sehat Hospital, Karachi, Pakistan
}

*Corresponding Author: Syeda Beenish Bareeqa, Jinnah Medical and Dental College, Karachi, Pakistan, Email: syedabeenishbareeqa@ gmail.com

\begin{abstract}
Introduction: Blood donation is an act of voluntarily drawing one's own blood and donating it for wellbeing of needy person. In spite of extensive researches, a true substitute for blood may not be available for many years which leave us with no choice other than blood donation.
\end{abstract}

Objective: The purpose of our study was to assess the major fearing factors towards voluntary blood donation among medical students of a tertiary care hospital and to find determinants which hinder them from voluntary blood donation.

Materials and Methods: A case-control study was conducted on 102 medical students of King Edward Medical University Lahore who were selected by simple random sampling. Study duration was 06 months. A pretested questionnaire was used and data was entered and analyzed on SPSS version 16. Bivariate analysis was done and multivariate logistic regression was applied to significant factors.

Result: The total number of participants $(N)=102$, out of them, 50\% were male and $50 \%$ were female. As per multivariate logistic regression model, the significant factors leading to avoidance of blood donation were gender (OR=0.011, 95\% CI (0.002-0.054), fear of needles (OR=0.910, 95\% CI( 0.141-5.888), fear of infections ( OR=0.240, 95\% CI=0.052-1.106), lack of septic measures (OR=0.511, 95\% CI( 0.083-3.157), parents permission $(O R=2.068,95 \%$ CI (0.480-8.909) and peer pressure $(O R=0.174,95 \%$ CI (0.0122.556).

Conclusion: Our study showed that males donate blood more frequently than females. Other main factors leading to avoidance of blood donation are fear of catching deadly infections and lack of proper septic measures. Pear pressure and parental influences are also found to have impact on blood donation among medical students.

Keywords: Avoidance, Blood donation, Medical students, aseptic measures

\section{INTRODUCTION}

Blood donation is an act of voluntarily drawing one's own blood and donating it for wellbeing of needy person. In spite of extensive researches, a true substitute for blood may not be available for many years which leave us with no choice other than blood donation(1). Millions of blood units are collected from donors every year but demand is increasing day by day that claims for timely provision of blood(2). Blood transfusion is required to deal with complications during pregnancy, blood disorders in children, traumatic events on large scale and in many other debilitating illnesses. More than 25\% of maternal deaths could be avoided by provision of safe blood(3, 4).

According to an estimate of Pakistan Red Crescent Society, over 80 million units of blood are donated all over the world every year. Unfortunately only $39 \%$ of this amount is collected in developing countries which provide accommodation to $82 \%$ of global population. According to a research of WHO done by Fordham J. and Dhingra N. in Geneva in 2010, a minimum of $1 \%$ of population is needed to meet nation's most basic requirement for blood(5). A research paper by Asif N, Kokhar N. and Ilahi F. concluded that in Pakistan more than 1.5 million 
pints of blood are collected each year. Among them about $65 \%$ is from replacement donors, $25 \%$ from volunteer donors and about $10 \%$ from professional donors(6).

Medical students generally have better understanding about the need of blood in a population. A research conducted by Hosain GM, Anisuzzaman M. and Begum A. on Dhaka University students in Bangladesh revealed that in comparison to general population, university students have a higher level of knowledge and more positive attitude towards blood donation(7). Grossly a study conducted by Giles M, McClenahan C, Cairns E. and Mallet J. in 2004 depicts that $17.6 \%$ students are donor including 7.6\% medical and $10 \%$ non-medical. Reluctance among students for blood donation is mainly due to psychological factors like fear of being sick or fainting(8).

Needle-borne infections like hepatitis and AIDs is a major restraining factor from blood donation. A study conducted by Hauri AM concluded that in developing countries, the majority of infections are attributable to parenteral exposure in health care settings, particularly unsafe injections with contaminated sharps(9). Studies conducted by Rehman M in 2002 and Purow D. in 2004 concluded that prior to introduction of donor's blood, screening for hepatitis, AIDs and other blood-borne diseases are necessary. Lack of quality screening method is associated with significant risk of acquisition of $\mathrm{HBV}$ and HCV (10, 11). In 1984, Gallow RC first linked AIDS to blood transfusion. By 2003 contaminated blood and blood products accounted for $7 \%$ of the total transmission of HIV/AIDS in Pakistan(12). While in 2004, Olaiya MA and Alakija W discussed in their research that blood donation is avoided because of various fears expressed by people and mainly done for beneficial reasons. Only $6.46 \%$ of donors donate blood to make money(13).

Our objective is to find the major causes due to which blood donation is not so popular among medical students, despite of having high knowledge and better understanding to this community problem.

\section{MATERIAL AND METHODS}

A case-control study was conducted from August 2016 to February 2017 on medical students of King Edward Medical University, Lahore. Sample size collected over the period of 06 months was of 102 medical students. Current undergraduates of KEMU from first year to final year M.B.B.S were included while every other group of medicine except M.B.B.S was excluded. Non-cooperative students were also excluded from the study. Participants were divided into case (non-donors) and control (donors) groups using simple random sampling technique. Informed consent was taken from all the students who participated in our study. A pretested questionnaire was distributed among all participants. Both groups were compared using Bivariate analysis. Variables included in bivariate analysis were Gender, Blood group, Type of family; Family background, Fear of needles, Fear of sight of blood, Fear of fainting, Fear of screening, Fear of catching deadly infections, Unsafe setup, Lack of septic measures, No time for voluntary blood donations, Tiring procedure, Time consuming procedure, Need of rest after blood donation, Religiously permitted, Parents permission, Peer pressure, Only males can donate and Both females and males can donate. Frequencies and percentages were calculated for demographic data. Chi-Square test was applied to calculate the association among gender and blood donation. Multivariate logistic regression was applied to the significant variables. SPSS version 16 was used for data entering, management and analysis.

\section{RESUltS}

The total number of participants $(\mathrm{N})=102$, out of them $50 \%$ were male and $50 \%$ were female. The mean age of participants calculated was 21.17 \pm 1.387 .

Table1. Demographic and Other Characteristics of the Study Group

\begin{tabular}{|c|c|c|}
\hline Characteristics & $\begin{array}{c}\text { Case (non- } \\
\text { donor) }\end{array}$ & $\begin{array}{l}\text { Control } \\
\text { (donor) }\end{array}$ \\
\hline $\begin{array}{ll}\text { Gender } & \\
\bullet & \text { Male } \\
\bullet & \text { Female }\end{array}$ & $\begin{array}{l}5(9.8 \%) \\
46(90.2 \%)\end{array}$ & $\begin{array}{l}46(90.2 \%) \\
5(9.8 \%)\end{array}$ \\
\hline $\begin{array}{ll}\text { Age } & \\
\text { - } & 18 \\
\text { - } & 19 \\
\text { - } & 20 \\
\text { - } & 21 \\
\text { - } & 22 \\
\text { - } & 23 \\
\text { - } & 24 \\
\text { - } & 25\end{array}$ & $\begin{array}{l}1 \\
4 \\
10 \\
11 \\
25 \\
0 \\
0 \\
0\end{array}$ & $\begin{array}{l}3 \\
4 \\
10 \\
10 \\
13 \\
7 \\
3 \\
1\end{array}$ \\
\hline \begin{tabular}{ll}
\multicolumn{2}{l}{ Blood group } \\
- & $\mathrm{A}+$ \\
- & $\mathrm{A}-$ \\
- & $\mathrm{B}+$ \\
- & $\mathrm{B}-$ \\
- & $\mathrm{AB}+$ \\
- & $\mathrm{AB}-$ \\
- & $\mathrm{O}+$ \\
\end{tabular} & $\begin{array}{l}9 \\
0 \\
20 \\
0 \\
9 \\
0 \\
11 \\
2 \\
\end{array}$ & $\begin{array}{l}13 \\
1 \\
12 \\
3 \\
2 \\
1 \\
17 \\
2 \\
\end{array}$ \\
\hline
\end{tabular}


Factors Refraining Medical Students from Blood Donation; a Tertiary Care Experience from a Medical College of Pakistan

\begin{tabular}{|c|c|c|c|c|c|}
\hline $\begin{array}{l}\text { Family } \\
\text { background } \\
\text { - Urban }\end{array}$ & $\begin{array}{l}33(64.70 \%) \\
18(35.29 \%)\end{array}$ & $\begin{array}{l}29(56.86 \%) \\
22(43.13 \%)\end{array}$ & \begin{tabular}{ll}
\multicolumn{2}{l}{ Type of family } \\
$\bullet$ & Nuclear \\
$\bullet$ & Joint
\end{tabular} & $\begin{array}{l}43(84.3 \%) \\
8(15.7 \%)\end{array}$ & $\begin{array}{l}37(72.5 \%) \\
14(27.5 \%)\end{array}$ \\
\hline
\end{tabular}

Table2. Bivariate analysis was done of all the variables and following results were obtained

\begin{tabular}{|c|c|c|c|c|c|c|c|}
\hline \multirow{2}{*}{ VARIABLES } & \multirow[t]{2}{*}{ CASE $n=51$} & \multirow{2}{*}{$\begin{array}{l}\text { CONTROL } \\
n=51\end{array}$} & \multirow{2}{*}{$\begin{array}{l}\text { CRUDE } \\
\text { ODDS } \\
\text { RATIO } \\
\end{array}$} & \multicolumn{2}{|c|}{$95 \% \mathrm{CI}$} & \multirow{2}{*}{$\begin{array}{l}\text { CHI } \\
\text { SQUARE } \\
\text { VALUE } \\
\end{array}$} & \multirow{2}{*}{$\begin{array}{l}\text { P- } \\
\text { VAL } \\
\text { UE }\end{array}$} \\
\hline & & & & LOWER & $\begin{array}{l}\text { UPPE } \\
\mathbf{R}\end{array}$ & & \\
\hline \multicolumn{8}{|l|}{ Gender } \\
\hline \multirow{2}{*}{$\begin{array}{ll} & \text { Male } \\
- & \text { Female }\end{array}$} & $5(9.8 \%)$ & $46(90.2 \%)$ & \multirow[t]{2}{*}{0.012} & \multirow[t]{2}{*}{0.003} & \multirow[t]{2}{*}{0.044} & \multirow[t]{2}{*}{65.922} & \multirow[t]{2}{*}{0.000} \\
\hline & $46(90.2 \%)$ & $5(9.8 \%)$ & & & & & \\
\hline \multicolumn{8}{|l|}{ Type of Family } \\
\hline \multirow{2}{*}{$\begin{array}{ll}\text { - } & \text { Nuclear } \\
& \text { Joint }\end{array}$} & $43(84.3 \%)$ & $37(72.5 \%)$ & \multirow[t]{2}{*}{2.034} & \multirow[t]{2}{*}{0.768} & \multirow[t]{2}{*}{5.384} & \multirow[t]{2}{*}{2.086} & \multirow[t]{2}{*}{0.149} \\
\hline & $8(15.7 \%)$ & $14(27.5 \%)$ & & & & & \\
\hline \multicolumn{8}{|l|}{ Family background } \\
\hline Urban & $33(64.70 \%)$ & $29(56.86 \%)$ & 1.391 & 0.626 & 3.089 & 0.658 & 0.417 \\
\hline Rural & $18(35.29 \%)$ & $22(43.13 \%)$ & & & & & \\
\hline \multicolumn{8}{|l|}{ Fear of Needles } \\
\hline $\begin{array}{ll} & \text { Yes }\end{array}$ & $16(31.4 \%)$ & $5(9.80 \%)$ & 0.238 & 0.079 & 0.712 & 7.256 & 0.007 \\
\hline No & $35(68.6 \%)$ & $46(90.2 \%)$ & & & & & \\
\hline $\begin{array}{l}\text { Fear of Sight of } \\
\text { Blood }\end{array}$ & & & & & & & \\
\hline - $\quad$ Yes & $4(7.84 \%)$ & $7(13.72 \%)$ & 1.869 & 0.512 & 6.828 & 0.917 & 0.338 \\
\hline No & $47(92.16 \%)$ & $44(86.27 \%)$ & & & & & \\
\hline Fear of Fainting & & & & & & & \\
\hline Yes & $10(19.61 \%)$ & $9(17.65 \%)$ & 0.879 & 0.324 & 2.384 & 0.065 & 0.799 \\
\hline No & $41(80.39 \%)$ & $42(82.35 \%)$ & & & & & \\
\hline Fear of Screening & & & & & & & \\
\hline - $\quad$ Yes & $11(21.56 \%)$ & $13(25.49 \%)$ & 1.244 & 0.497 & 3.114 & 0.218 & 0.641 \\
\hline No & $40(78.43 \%)$ & $38(74.51 \%)$ & & & & & \\
\hline $\begin{array}{l}\text { Fear of catching } \\
\text { deadly infections }\end{array}$ & & & & & & & \\
\hline • Yes & $39(76.47 \%)$ & $28(54.90 \%)$ & 0.375 & 0.160 & 0.877 & 5263 & 0.022 \\
\hline - $\quad$ No & $12(23.53 \%)$ & $23(45.09 \%)$ & & & & & \\
\hline Unsafe setup & & & & & & & \\
\hline Yes & $36(70.59 \%)$ & $35(68.63 \%)$ & & & & & \\
\hline No & $15(29.41 \%)$ & $16(31.37 \%)$ & 0.911 & 0.392 & 2.120 & 0.046 & 0.830 \\
\hline $\begin{array}{l}\text { Lack of proper } \\
\text { septic measures }\end{array}$ & & & & & & & \\
\hline - $\quad$ Yes & $47(92.16 \%)$ & $34(66.66 \%)$ & 0.170 & 0.053 & 0.551 & 10.134 & 0.001 \\
\hline - $\quad$ No & $4(7.84 \%)$ & $17(33.33 \%)$ & & & & & \\
\hline $\begin{array}{lr}\text { No time } & \text { for } \\
\text { voluntary } \\
\text { donation }\end{array}$ & & & & & & & \\
\hline - $\quad$ Yes & $11(21.57 \%)$ & $17(33.33 \%)$ & 1.818 & 0.750 & 4.408 & 1.772 & 0.183 \\
\hline No & $40(78.43 \%)$ & $34(66.66 \%)$ & & & & & \\
\hline Tiring procedure & & & & & & & \\
\hline - $\quad$ Yes & $15(29.41 \%)$ & $13(25.49 \%)$ & 0.821 & 0.343 & 1.963 & 0.197 & 0.657 \\
\hline - $\quad$ No & $36(70.59 \%)$ & $38(74.51 \%)$ & & & & & \\
\hline $\begin{array}{l}\text { Time consuming } \\
\text { procedure }\end{array}$ & & & & & & & \\
\hline - $\quad$ Yes & $14(27.45 \%)$ & $10(19.61 \%)$ & 0.645 & 0.256 & 1.626 & 0.872 & 0.350 \\
\hline - $\quad$ No & $37(72.55 \%)$ & $41(80.39 \%)$ & & & & & \\
\hline $\begin{array}{l}\text { Need of rest after } \\
\text { blood donation }\end{array}$ & & & & & & & \\
\hline - $\quad$ Yes & $36(70.59 \%)$ & $40(78.43 \%)$ & 1.515 & 0.617 & 3.728 & 0,826 & 0.363 \\
\hline No & $15(29.41 \%)$ & $11(21.57 \%)$ & & & & & \\
\hline Religiously & & & & & & & \\
\hline
\end{tabular}


Factors Refraining Medical Students from Blood Donation; a Tertiary Care Experience from a Medical College of Pakistan

\begin{tabular}{|c|c|c|c|c|c|c|c|}
\hline \multicolumn{8}{|l|}{ permitted } \\
\hline \multirow{2}{*}{$\begin{array}{ll}\text { - } & \text { Yes } \\
\text { - } & \text { No } \\
\end{array}$} & $49(96.08 \%)$ & $50(98.04 \%)$ & 2.041 & 0.179 & 23.241 & 0.343 & 0.558 \\
\hline & $2(3.92 \%)$ & $1(1.96 \%)$ & & & & & \\
\hline \multicolumn{8}{|c|}{ Parents' permission } \\
\hline \multirow{2}{*}{$\begin{array}{ll}- & \text { Yes } \\
- & \text { No } \\
\end{array}$} & $26(50.98 \%)$ & $36(70.59 \%)$ & \multirow[t]{2}{*}{2.308} & \multirow[t]{2}{*}{1.021} & \multirow[t]{2}{*}{5.213} & \multirow[t]{2}{*}{4.113} & \multirow[t]{2}{*}{0.043} \\
\hline & $25(49.02 \%)$ & $15(29.41 \%)$ & & & & & \\
\hline \multirow{3}{*}{$\begin{array}{lc}\text { Peer } & \text { pressure } \\
\text { - } & \text { Yes } \\
\text { - } & \text { No } \\
\end{array}$} & & & \multirow[b]{3}{*}{0.256} & \multirow[b]{3}{*}{0.066} & \multirow[b]{3}{*}{0.994} & \multirow[b]{3}{*}{4.320} & \multirow[b]{3}{*}{0.038} \\
\hline & $10(19.61 \%)$ & $3(5.88 \%)$ & & & & & \\
\hline & $41(80.39 \%)$ & $48(94.12 \%)$ & & & & & \\
\hline \multicolumn{8}{|c|}{$\begin{array}{l}\text { Only males can } \\
\text { donate }\end{array}$} \\
\hline \multirow{2}{*}{$\begin{array}{ll}- & \text { Yes } \\
\text { - } & \text { No } \\
\end{array}$} & $6(11.76 \%)$ & $4(7.84 \%)$ & \multirow[t]{2}{*}{0.638} & \multirow[t]{2}{*}{0.169} & \multirow[t]{2}{*}{2.412} & \multirow[t]{2}{*}{0.443} & \multirow[t]{2}{*}{0.505} \\
\hline & $45(88.24 \%)$ & $47(92.16 \%)$ & & & & & \\
\hline \multicolumn{8}{|c|}{$\begin{array}{l}\text { Both males and } \\
\text { females can donate }\end{array}$} \\
\hline \multirow{2}{*}{$\begin{array}{ll}- & \text { Yes } \\
\text { - } & \mathrm{No}\end{array}$} & $44(86.27 \%)$ & $47(92.16 \%)$ & \multirow[t]{2}{*}{1.869} & \multirow[t]{2}{*}{0.512} & \multirow[t]{2}{*}{6.828} & \multirow[t]{2}{*}{0.917} & \multirow[t]{2}{*}{0.338} \\
\hline & $7(13.73 \%)$ & $4(7.84 \%)$ & & & & & \\
\hline
\end{tabular}

Table3. Multivariate analysis was done for only those variables whose P-value was significant $(<0.05)$ in Bivariate analysis.

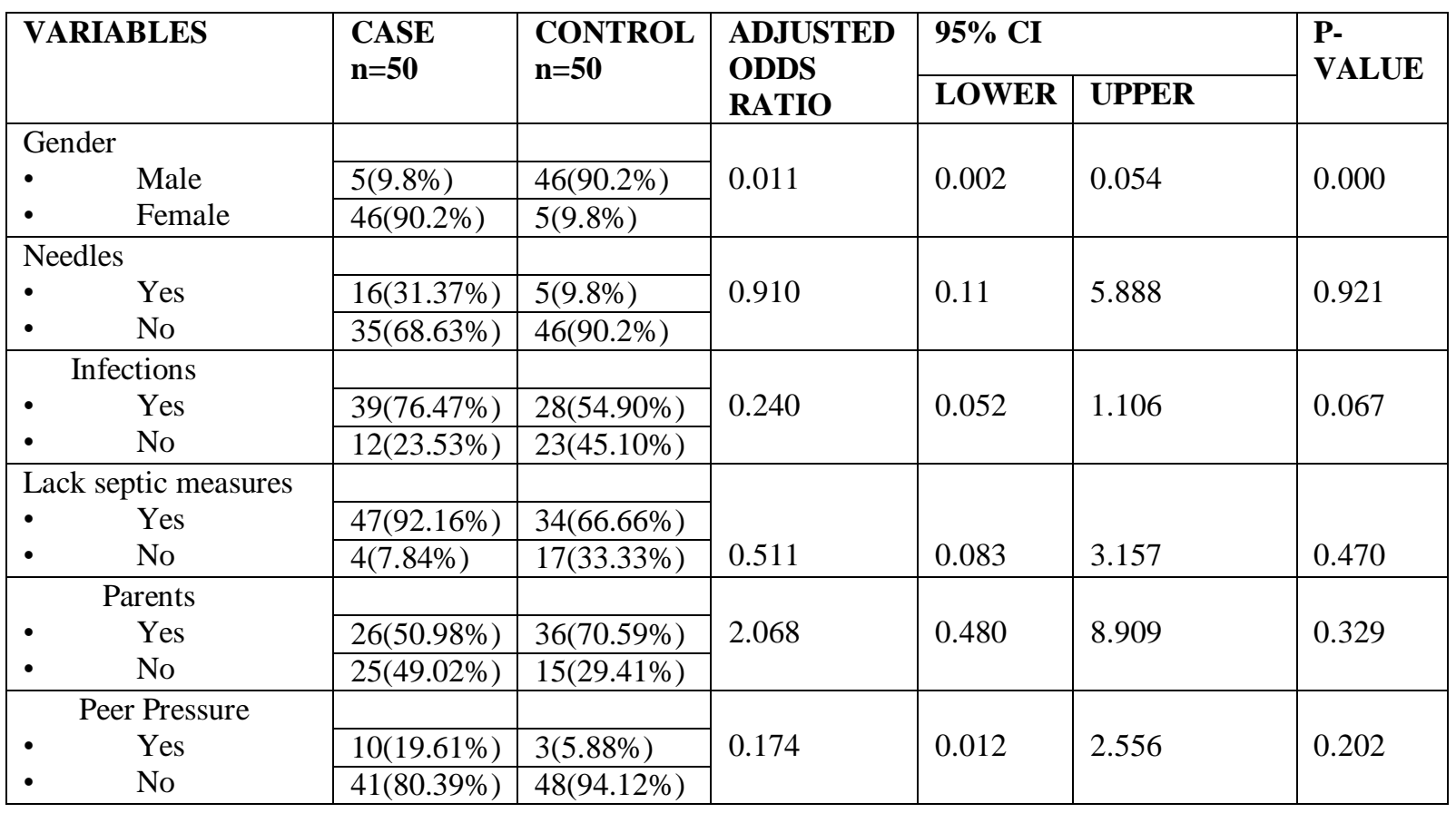

In our study $50 \%$ of the participants were donors and $50 \%$ of them were non donors. In case group, females $(90.2 \%)$ were being more frequent than males whereas in control group, majority of population was male $(90.2 \%)$. In Table-2, among all the participants, $20.6 \%$ had the fear of needles whereas $79.4 \%$ were not afraid of it. Fear of sight of blood was present in only $10.8 \%$ of the population while $89.2 \%$ had no such fear. $18.6 \%$ of the study population had the fear of fainting as compared to $81.4 \%$ of the students which did not have this fear. Results also showed that $23.5 \%$ were afraid of screening and $76.5 \%$ said that they had no fear of screening. $67.5 \%$ of the subjects were frightened of catching deadly infections and
$34.3 \%$ had no such fear. Unsafe setup was a prevalent cause of not donating blood in $69.6 \%$ and $30.4 \%$ did not show this concern.79.4\% of our study group refrained from blood donation because of lack of proper septic measures whereas $20.6 \%$ were satisfied with the septic measures. $27.5 \%$ of the students said that they had no time for voluntary blood donation and $23.5 \%$ considered it a time consuming procedure. $27.5 \%$ were of the view that blood donation was a tiring procedure and $72.5 \%$ did not think of it to be tiresome. Due to this reason $74.5 \%$ of the study population thought rest should be taken after donating blood. As mentioned in Table-3, 97.1\% of the participants did not consider religion as a barrier to blood 
donation. Superstitions and social norms had no effect on blood donation attitude of students. $60.8 \%$ of the subjects were reluctant to donate blood due to parents influence. While peer pressure was a significant hindering factor in $12.7 \%$ of the participants. The result showed that $9.8 \%$ of the study group said that only males can donate blood whereas $89.2 \%$ said that both males and females can donate blood

\section{DISCUSSION}

The supply demand discrepancy of blood and blood products is a major issue worldwide. The ever increasing demand for blood can only be met by sufficient amount of blood donations. Compared to general population, medical students have higher knowledge regarding blood donation .The reluctance of medical students towards voluntary blood donation can result from a number of factors. We studied 19 determinants which were considered to be associated with the avoidance of blood donation among the medical students.

Our study showed that $90.2 \%$ of the blood donors were male and only $9.8 \%$ were females clearly indicating the association of gender with voluntary blood donation. The $\mathrm{p}$ value was found to be significant $(0.001)$. Our result was strongly supported by a research conducted at Fauji Foundation hospital, Rawalpindi where $97.05 \%$ of the donors were male(14). This gender variation was further supported by the study conducted by Gillespie et al., showing male being more prevalent among blood donors [19]. A study conducted in 2014 by Dilsad S. showed that most of female participants thought that men could donate blood, but it was not favorable for the women since they were already losing blood through menstruation(15)

One of the major determinants that cause avoidance of blood donation is the fear of needles. Our research brings out that $31.4 \%$ of the non donors were afraid of needles. The $\mathrm{p}$ value was 0.007 for this factor. This was the basis of their refrain from the blood donation. Study conducted in China by Zaller $\mathrm{N}$ et al., also favors our results(16). Our results are further supported by study conducted in India(17).

Parent's permission is an important factor that influences the attitude of medical students towards blood donation. In our study, $49.02 \%$ of the non donors were reluctant to donate blood due to their parental influence .This lack of enthusiasm among parents is due to their lack of knowledge about importance of blood donation.
The $\mathrm{p}$ value was 0.043 for this factor. This is supported by study conducted in Karachi(18). A study conducted by Gillani I,et al. supported that parental education has an overall impact on decisions made by their children which in turn affects voluntary blood donation(19).

The results of our study suggested that fear of catching infections was predominant factor in preventing students from blood donation. Data collected showed that $76.47 \%(\mathrm{p}=0.022)$ of the cases had a fear of catching deadly infections. This was supported by a study of Giles(8) that reported the fear of catching infection as one of the prevailing beliefs among non donors. Grossman's survey of young African American women about barriers and motivators of blood donation indicated fear of contracting infectious diseases as a primary reason for not donating blood(20). Razzak M. concluded in a study that $68 \%$ of non blood donors perceived donating blood as a source of diseases transmission(21).

Lack of proper septic measures was an important contributing factor for not donating blood. $92.16 \%$ of the non donors (case group) refrained from donating blood due to improper septic measures $(\mathrm{p}=0.001)$. The study by Vasquez M, Ibbara P, Maldonado M concluded that compromised sterilization of instruments refrained $73.4 \%$ of survey participants from donating(22). The spreading index for HIV and HBV combined is 26.75 per 10,000 donations in Punjab, Pakistan as per studied by Mahfooz-urRahman(11).

Peer pressure also appears to be a contributing factor for not donating blood in our study with $\mathrm{P}$ value of 0.038 . Our results were in correspondence with the study conducted by Sharma R. in Delhi (23) and Perera DAK in Sri Lanka (24) that showed the peer and family pressure as a significant hindrance in voluntarily donating blood.

The psychological factors such as fear of sight of blood and fear of fainting also affect the voluntary blood donation. Our data showed that $86.27 \%$ of the blood donors did not have fear of sight of blood. A study done by JuarezHYPERLINK

"http://www.ncbi.nlm.nih.gov/pubmed/?term=Ju $\%$ C3\%A1rez-

Oca\%C3\%B1a\%20S\%5BAuthor\%5D\&cauthor $=$ true\&cauthor_uid=11519355"OcanHYPERLI NK

"http://www.ncbi.nlm.nih.gov/pubmed/?term=Ju $\%$ C3\%A1rez- 
Oca\%C3\%B1a\%20S\%5BAuthor\%5D\&cauthor $=$ true\&cauthor_uid=11519355"aHYPERLINK "http://www.ncbi.nlm.nih.gov/pubmed/?term=Ju $\%$ C3\%A1rez-

Oca\%C3\%B1a\%20S\%5BAuthor\%5D\&cauthor $=$ true $\&$ cauthor_uid $=11519355^{\prime \prime} \mathrm{S}$ showed that attitudes influencing avoidance of blood donation were fear of sight of blood $(\mathrm{OR}+5.2$, 95\% CI 1.3-21.4)(25).

$82.35 \%$ of the blood donors (control group) had no fear of fainting and $7.84 \%$ of the non donors suffered from fear of fainting. This was supported by research done by France CR., et al that showed $56.7 \%$ of non fearful blood donors had no vaso-vagal reaction after blood donation as compared to the $33.2 \%$ of fearful donors who experienced fainting(26). A study conducted by Japanese Red Cross Tokyo Blood Centre (JRC) in 2007 shows that most frequent side effect following whole blood donation is vaso-vagal reaction (VVR), $67 \%$ cases of VVR were reported for $1.18 \%$ blood donation(27). The results of a study done by Dilsad S.,et al showed that anxiety about the procedure (fear of fainting ) leads to avoidance of blood donation(15).

$74.51 \%$ of the blood donors had no fear of screening .On the other hand $21.56 \%$ of the non donors (case group) had a fear of screening. Salaudeen AG, Musa OI and Awoyemi AO in a community survey on blood donation practices concluded that the fear of HIV screening was a major hindrance and limitation to voluntary blood donation(28).

36 subjects $(70.59 \%)$ of the case group $(n=51)$ thought that blood donation was not safe in our current setup. In Pakistan, prior to donor screening for Hepatitis, transfusion of blood was associated with significant risk of acquisition of $\mathrm{HCV}$ and HBV. Holland PV reviewed that risk of $\mathrm{HCV}$ infection by transfusion is 1 in 3,300(16). A study conducted at Karachi shows that among 148268 total donors, $1.03 \%$ donors were reactive for HIV and Treponema pallidum of which $99.94 \%$ were males of younger age group (18-30) years (29)

Since the subjects of our research are medical students so time management is very important. Our result showed that $21.57 \%$ of students were not donating blood because of lack of time. A study conducted by Alam $\mathrm{M}$ et al., also proved that population of developing countries consider lack of time as a barrier to blood donation (30).Issues of time and frequency of blood donation are related. Our result showed that $27.45 \%$ of the non donors consider it as a time consuming procedure .A study conducted by Thomson RA et al., also indicated that there is reduction in the frequency of blood donation due to lengthy protocol measures like history taking, inconvenient hours etc(31). This is in contrast with the study carried out in India where $60.60 \%$ non donors disagree with the time issue rather they were more concerned about the other parameters such $\mathrm{s}$ fear of needles(32).

Religious constrictions and beliefs were not found to be an influencing factor in our study. Only 3 out of 102 participants thought it to be an affecting element regarding blood donation decisions. This was supported by work of Mustafa $\mathrm{M}$ which showed only $0.7 \%$ of the University students linked religion and blood donation(33). The US National Survey of Family Growth also showed there is no relationship between religiosity and blood donation(34). But in contraindication to this, a Nigerian study (35) found that $20.3 \%$ of their study population would not donate blood mainly due to religious beliefs. It was also shown by Jehovah's witnesses $(36,37)$.

Blood donation was regarded as a tiring process by $29.4 \%$ of the non donors and $25.49 \%$ of the donors in our study which correlates with an Indian study done by Sharma RK according to which $40 \%$ of the study population showed the same concern(17). Our results also showed that $70.59 \%$ of the non donors and $78.43 \%$ of the donors believed that rest should be taken after donating blood.

In our study only $10.7 \%$ of the total study population said that only male can donate blood while $89.21 \%$ students were of the view that both genders have equal potential to donate blood. But the majority of the donors participating in our research were male. Our research was supported by Bilal M's work.68\% of the participants were against the perception that men can donate blood because women do not feel as strong as men(38). Contrarily Dilsad S's study on the attitudes and beliefs of Turkish Women regarding blood donation showed that All the participants (100\%) thought that men could donate blood, but it was not favorable for the women since they were "already losing blood through menstruation"(15).

Family setup and background may have an influence on voluntary activities such as blood 
donation. $72.5 \%$ of the voluntary blood donors (control group) whereas $27.5 \%$ of non donors belonged to nuclear type of family. $64.70 \%$ of the non donors (case group) were city dwellers where as $35.29 \%$ had a rural family background.

\section{Limitations}

The only limitation of our study was sample size which was relatively small

\section{CONClusion}

Our study showed that gender is a significant determinant of blood donation. Males donate blood more frequently than females. Most of people avoid blood donation because of fear of catching deadly infections. Other main factors leading to avoidance of voluntary blood donation are lack of proper septic measures and fear of needles. Our study further showed that voluntary blood donation is influenced by peer pressure and a lot of non-donors avoid blood donation because their parents do not allow them to. Our study assessed the level of knowledge and misconceptions of medical students regarding blood donation. Our research can help promote knowledge and eliminate misconceptions leading to avoidance of blood donation as blood donation is a life-saving act and a pinch of blood can save precious lives.

\section{REFERENCES}

[1] Lowe KC, Ferguson E. Benefit and risk perceptions in transfusion medicine: blood and blood substitutes. Journal of internal medicine. 2003;253(5):498-507.

[2] Damesyn MA, Glynn SA, Schreiber GB, Ownby HE, Bethel J, Fridey J, et al. Behavioral and infectious disease risks in young blood donors: implications for recruitment. Transfusion. 2003;43(11):1596-603.

[3] Hensher M, Price M, Adomakoh S. Referral hospitals. Disease control priorities in developing countries. 2006;66:1229-12.

[4] Weiser TG, Regenbogen SE, Thompson KD, Haynes AB, Lipsitz SR, Berry WR, et al. An estimation of the global volume of surgery: a modelling strategy based on available data. The Lancet. 2008;372(9633):139-44.

[5] Fordham J, Dhingra N. Towards 100\% voluntary blood donation: a global framework for action. World Health Organization, Geneva. 2010.

[6] Asif N, Khokhar N, Ilahi F. Sero-prevalence of $\mathrm{HBV}, \mathrm{HCV}$, and HIV infection among voluntary non remunerated \& replacement donors in Northern Pakistan. Pakistan journal of medical sciences. 2004;20(1):24-8.
[7] Hosain GM, Anisuzzaman M, Begum A. Knowledge and attitude towards voluntary blood donation among Dhaka University students in Bangladesh. East African medical journal. 1997;74(9):549-53.

[8] Giles M, McClenahan C, Cairns E, Mallet J. An application of the theory of planned behaviour to blood donation: the importance of selfefficacy. Health Education Research. 2004;19(4):380-91.

[9] Hauri AM, Armstrong GL, Hutin YJF. The global burden of disease attributable to contaminated injections given in health care settings. International journal of STD \& AIDS. 2004;15(1):7-16.

[10] Purow DB, Jacobson IM. Slowing the progression of chronic hepatitis B: early antiviral therapy can help minimize complications. Postgraduate medicine. 2003;114(1):65-76.

[11] Rahman Mu, Akhtar GN, Lodhi Y. Transfusion transmitted HIV and HBV infections in Punjab Pakistan. Pakistan journal of medical sciences. 2002;18(1):18-25.

[12] Gallo RC, Salahuddin SZ, Popovic M, Shearer GM, Kaplan M, Haynes BF, et al. Frequent detection and isolation of cytopathic retroviruses (HTLV-III). N Engl J Med. 1982;306:248.

[13] Olaiya MA, Alakija W, Ajala A, Olatunji RO. Knowledge, attitudes, beliefs and motivations towards blood donations among blood donors in Lagos, Nigeria. Transfusion Medicine. 2004;14(1):13-7.

[14] Masood R, Sardar MA, Mallhi AA. Seroprevalence of hepatitis B and C among the healthy blood donors at Fauji Foundation Hospital, Rawalpindi. Pak J Med Sci. 2007;23:64-7.

[15] Dilsad S, Tanriover O, Hidiroglu S, Gurbuz Y, Karavus M. Knowledge, attitudes and beliefs of Turkish women towards blood donation. JPMA The Journal of the Pakistan Medical Association. 2014;64(8):869-73.

[16] Zaller N, Nelson KE, Ness P, Wen G, Bai X, Shan H. Knowledge, attitude and practice survey regarding blood donation in a Northwestern Chinese city. Transfusion Medicine. 2005;15(4):277-86.

[17] Mishra SK, Sachdev S, Marwaha N, Avasthi A. Study of knowledge and attitude among college-going students toward voluntary blood donation from north India. Journal of blood medicine. 2016;7:19.

[18] Ahmed Z, Zafar M, Khan AA, Anjum MU, Siddique MA. Knowledge, attitude and practices about blood donation among undergraduate medical students in Karachi. 
Journal of Infectious Diseases and Therapy. 2014.

[19] Gilani I, Kayani ZA, Atique M. Knowledge, attitude and practices (kap) regarding blood donation prevalent in medical and paramedical personnel. J Coll Physicians Surg Pak. 2007;17(8):473-76.

[20] Grossman B, Watkins AR, Fleming F, DeBaun MR. Barriers and motivators to blood and cord blood donations in young Africanâ€承merican women. American journal of hematology. 2005;78(3):198-202.

[21] Malik MR, Majid S, Laghari MS. Determinants of blood donation behaviour of general public in Pakistan. Pak J Med Health Sci. 2010;4(1):137-42.

[22] VÃ $;$ squez M, Ibarra P, Maldonado Mn. Blood donation: knowledge and attitudes of a university population in Chile. Revista Panamericana de Salud PÃ $\tilde{A}^{\circ}$ blica. 2007;22(5):323-8

[23] Sharma R, Madan N, Venkatesh S, Ichhpujani RL, Lal S. Factors influencing blood donations and the rational use of blood. 2010.

[24] Perera DAK, Dharmaratne SK, Kendangamuwa Kwcuk GLPS. Determine The Factors Affecting The Blood Donors Of Selecting Blood Donor Program Me In Western Province, Sri Lanka. International Journal of Scientific \& Technological Research. 2015;4(11):148-57.

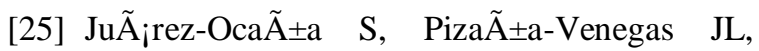
Farfan-Canto JM, Espinosa-Acevedo FJ, Fajardo-Gutierrez A. Factors that influence non-donation of blood in relatives of patients at a pediatric hospital. Gaceta medica de Mexico. 2000;137(4):315-22.

[26] France CR, France JL, Carlson BW, Himawan LK, Stephens KY, Frameâ€? Brown TA, et al. Fear of blood draws, vasovagal reactions, and retention among high school donors. Transfusion. 2014;54(3pt2):918-24.

[27] Odajima T, Takanashi M, Sugimori H, Tanba T, Yoshinaga K, Motoji $\mathrm{T}$, et al. Impact of Elevated Hemoglobin and Serum Protein on Vasovagal Reaction from Blood Donation. PloS one. 2016;11(2):e0148854.
[28] Holland PV. Overview: diagnostic tests for viral infections transmitted by blood. Nuclear medicine and biology. 1994;21(3):407-17.

[29] Sania Murad MD, Biag MA. Trends of Venereal Infections among Healthy Blood Donors at Karachi. Archives of Iranian medicine. 2016;19(3):192.

[30] Alam M, Masalmeh DBD. Knowledge, attitudes and practices regarding blood donation among the Saudi population. Saudi Medical Journal. 2004;25(3):318-21.

[31] Thomson RA, Bethel J, Lo AY, Ownby HE, Nass CC, Williams AE. Retention of â€œsafeâ€? blood donors. The retrovirus epidemiology donor study. Transfusion. 1998;38(4):359-67.

[32] Sharma RK VS, Sharma M, Pugazhendi S. . Voluntary Blood Donation:Attitude and Practice among Indian Adults. Journal of Community Medicine and Health. 2016.

[33] Mustafa M AE, Al-Rukbanc MO Attitude Towards Blood Donation Among University Students. Int J Sci: Basic Appl Res. 2015;19(2).

[34] Gillum RF, Masters KS. Religiousness and blood donation: findings from a national survey. Journal of health psychology. 2010;15(2):16372.

[35] Okpara RA. Attitudes of Nigerians towards blood donation and blood transfusion. Tropical and geographical medicine. 1989;41(1):89-93.

[36] Rosengart TK, Helm RE, DeBois WJ, Garcia N, Krieger KH, Isom OW. Open heart operations without transfusion using a multimodality blood conservation strategy in 50 Jehovah's Witness patients: implications for a" bloodless" surgical technique. Journal of the American College of Surgeons. 1997;184(6):618-29.

[37] Mann MC, Votto J, Kambe J, McNamee MJ. Management of the severely anemic patient who refuses transfusion: lessons learned during the care of a Jehovah's Witness. Annals of internal medicine. 1992;117(12):1042-8.

[38] Bilal M, Haseeb A, Zahid I, Lashkerwala SS, Saeeduddin F, Saad M, et al. Knowledge, Attitudes and Perceptions Among Non-Blood Donor Female Health Care Professionals. Global journal of health science. 2016;8(4):203

\footnotetext{
Citation: Syeda Beenish Bareeq et al, Factors Refraining Medical Students from Blood Donation; a Tertiary Care Experience from a Medical College of Pakistan. ARC Journal of Public Health and Community Medicine. 2017; 2(3):13-20 doi:dx.doi.org/10.20431/2456-0596.0203003

Copyright: (C) 2017 Authors. This is an open-access article distributed under the terms of the Creative Commons Attribution License, which permits unrestricted use, distribution, and reproduction in any medium, provided the original author and source are credited.
} 